\title{
The Influence of Financial Knowledge, Financial Attitudes, Parental Income to Financial Management Behavior of Undergraduate Students in Economic Education, University of Flores - Ende
}

\author{
Maria Fatima Bongi Beribe ${ }^{1 *} \quad$ Prof. Drs. Yoyok Soesatyo, SH., MM., Ph.D ${ }^{2}$ \\ Dr. Pujiono, SE., Ak., M.Sc., CA ${ }^{2}$ \\ 1.Surabaya State University, Postgraduate Program, Economic Education. \\ Campus Lidah Wetan - Surabaya - Indonesia. Post Code 60213 \\ 2.Surabaya State University, Campus Ketintang-Surabaya
}

\begin{abstract}
This study aims to analyze (1) The influence of Financial Knowledge on Financial Management Behavior of S1 Economic Education students of the Flores-Ende University. (2) Effect of Financial Attitudes on Financial Management Behavior of S1 Economic Education students of the Flores-Ende university. (3) Effects of Parental Income on Financial Management Behavior of S1 Economic Education students of the University of Flores-Ende. This study uses primary data from the results of the distribution questionnaire to 73 6th semester students of Economic Education in accounting concentration. The analysis technique uses structural equation modeling based on Partial Least Square with Smart PLS 3.0 Software. Analysis of structural equation models with - Second Order Confirmatory Factor Analysis (CFA) with indicators in the form of Reflective. Based on the results of the RSquare test with a value of 0.742 states that Financial Knowledge, Financial Attitudes, Parental Income have a strong influence on the Financial Management Behavior of S1 Economic Education S. Facesents at the University of Flores-Ende. While the value of f-Square on the largest path coefficient is the influence of financial attitudes on Financial Management Behavior of 0.284, then the influence of Parental Income on Financial Management Behavior of 0.147 and the smallest influence is Financial Knowledge of 0.073. As for the indicators that influence each construct by $0,000<0.05$, it can be concluded that Financial Knowledge, Financial Attitudes and Parental Income simultaneously influence the Financial Management Behavior of S1 Economic Education students at the University of Flores-Ende. Financial Knowledge, Financial Attitudes and Parental Income also partially influences the Financial Management Behavior of Undergraduate Students in Economic Education at the University of Flores-Ende.
\end{abstract}

Keywords : Financial Management Behavior, Financial Knowledge, Financial Attitudes, Parental Income DOI: $10.7176 /$ RJFA/11-4-09

Publication date: February $29^{\text {th }} 2020$

\section{Introduction}

Financial management behavior began to be recognized and developed in the business and academic world in 1990. Financial management behavior is a decision making process through the determination, acquisition, allocation and utilization of financial resources (Mien and Thao, 2015). Behavior management of finances should be in the direction of $\mathrm{k}$ 's well, resulting in mencapa i go late that has been set. Similarly, the behavior of students in managing finances considering $\mathrm{h}$ ampir most students have financial constraints; this is due to students not having a fixed income so every month they rely on sending money from parents to make ends meet. For students who do not have income and are not at home with their parents, managing finances is not easy. Many obstacles faced, for example; delays in sending money from parents, lack of availability of funds to be used, running out of funds prematurely due to unexpected needs, or due to lack of planning, consumptive and wasteful lifestyle.

There are several empirical studies of financial management behavior with various variables that influence it. Mien and Thao (2015), found that financial knowledge has a significant relationship with financial management behavior. Robb and Woodyard (2011), said that subjective and objective financial knowledge influences financial management behavior. The same thing was found by Marsh (2006), that the higher a person's knowledge of finances, the wiser he would manage his finances. The cause of poor financial determination is the result of a lack of knowledge about finances early on.

In addition to knowledge of finance, the attitude of finance can also affect the behavior of financial management as d discovered by Mien and Thao (2015) that financial attitude positive effect on the behavior of financial management. Lim and Teo (1997) state that financial attitude is related to financial difficulties that are often experienced by adolescents.

Parental income can also affect student financial management behavior. Dorjana Nano (2015), Robb and woodyard (2011) say that parental income influences student financial management behavior. they found that students who had high income parents tended to behave better in managing their finances compared to students 
who had moderate or low income parents. Hilgert (2003) found that due to low income can negatively affect a person's behavior, for example paying bills on time.

\section{Theoritical review}

Financial management behavior is a behavior related to financial applications. Xiao and Dew (2011), behavior of financial management as a level of expertise in a person in the field of finance both in managing money, managing debt or managing savings and investment. Mien and Thao (2015), financial management behavior as the behavior in directing the flow of funds according to plan and gol $\mathrm{u}$ 's that have been set. Financial management behavior is also a determinant, acquisition, allocation and utilization of financial resources. Cliff Robb (2011), financial management behavior is a person's ability to manage finances in the form of cash flow management, emergency funds, insurance, loans, savings and investments.

Brent A. Marsh (2006) said that to measure the behavior of financial management can be seen from four indicators namely

- Organizing, which is behavior related to setting and achieving financial goals through planning, regulating, using, monitoring and evaluating

- Spending is a behavior related to someone's accuracy in estimating costs accurately and successfully carrying out an expenditure plan

- Saving (Savings) is the behavior of setting aside a portion of income or revenue as a reserve fund and investment for the future

- Squandering is the behavior of wanting to spend your funds without looking at the effect or influence on the financial situation.

\section{Financial knowledge}

Financial knowledge is the knowledge of finance that is owned by someone who can be applied in managing funds according to the plans and goals that have been set. Financial knowledge includes 4 aspects, namely a). General knowledge of personal finance, b) savings and loans, c). Insurance, d). Investation. (Chen and Volpe.1998) . S edangkan by Cliff Rob (2011), financial literacy is an individual's expertise in the financial sector are on the mark with the ability to manage financial and skilled use financial tools.

Brent A. Marsh (2006) said that to measure financial knowledge can be seen from four indicators namely

- $\quad$ Financial basics

Basic knowledge of procedures for financial management and effective financial decision making such as budgeting, emergency funds, time value of money and insurance

- Credit issue

Knowledge about credit and debt management consists of: factors that affect creditworthiness, consideration in making loans, credit characteristics, loan interest rates, loan term, and sources of obtaining credit and debt are financial knowledge that is needed to be able to use credit and debt wisely.

- Interest and taxes

Knowledge of compound interest and income tax

- Savings and investment

Knowledge of savings and investments related to rate of return (percentage increase in savings), inflation, tax considerations, liquidity, security (protection of savings if the bank is experiencing financial difficulties), and restrictions and charging fees for a particular transaction for withdrawal of deposits and other matters relating to investment .

\section{Financial attitude}

Financial attitude is defined as a condition of mind, views, opinions and judgments about one's personal finances which is then applied in the form of attitudes towards money (Pankow, 2003). Furhan in Mien and Thao (2015) explains concepts that reflect someone's financial attitudes such as; Obssesion is one's mindset about money and perception someone about good financial management in the future, power is the attitude of people use money as a tool to control others and for her money can solve the problem, effort is feeling feel deserve to have money from businesses already doing, inadequacy is the feeling of someone who was always short of money, retention is the state of a person who has a tendency to not want to spend money and security is the attitude of the tendency of someone who thinks that money is better kept separately (do not use financial instrument such as a bank account or make investments).

According to Brent A. Mars (2006) there are four indicators used to measure attitudes

- Orientation on personal finance is the perception of good financial management in the future.

- Debt philosophy yait u positive and negative attitudes towards debt.

- $\quad$ Financial Security

Financial security refers to peace of mind when someone who is not worried about his income is sufficient to cover his expenses; It also means that someone has enough money saved to cover an emergency and 
his future financial goals.

- $\quad$ Assessing Personal Finances

judge to uangan personally associated with that value or u quality person when using money and how relationships with others

\section{Parental income}

Nababan and Sadalia (2012) state that parental income is the level of income obtained by the respondent's parents for a month from salary, wages or other business results.

According to the Central Statistics Agency (2016) the level of income can be classified into four groups as listed in the following table

Table 2. 1. Income levels

\begin{tabular}{|c|l|l|}
\hline No & Total Income & Tiers \\
\hline 1 & $>$ IDR $3.500,000.00$ & Very high class \\
\hline 2 & IDR $2,500,000.00$ to Rp3,500,000.00 & High Group \\
\hline 3 & IDR $1.500,000.00$ to IDR $2,400,000.00$ & Medium group \\
\hline 4 & IDR $<1.500,000.00$ & Low class \\
\hline
\end{tabular}

Hypothesis development

The influence of financial knowledge on financial management behavior

Marsh (2006) says that financial knowledge refers to what someone knows about conflicts that occur in their finances, which are measured by their level of knowledge and understanding of financial concepts. Financial knowledge possessed by a person will influence behavior. The higher one's financial knowledge can result in good behavior in managing their finances, thus financial knowledge can influence a person to behave more responsibly towards his finances (Robb and Woodyard, 2011). Someone with financial knowledge will better understand financial problems and better their financial behavior. Thus the first hypothesis in this study is

$\mathrm{H} 1$ : Financial knowledge influences financial management behavior

The influence of financial attitude on financial management behavior

Attitude refers to how a person feels about personal financial problems, as measured by responses to a statement or opinion (Marsh, 2006). Meanwhile, financial management behavior refers to how a person behaves in relation to personal financial matters, measured by the actions of the individual (Marsh, 2006). He also stated that a person's personal financial behavior arises from his financial attitude, individuals who are not wise in responding to personal financial problems tend to have bad financial behavior . Based on the above explanation it can be said that financial attitudes have an influence on how a person regulates his financial behavior. Thus the second hypothesis in this study is

$\mathrm{H} 2$ : Financial attitude influences financial management behavior

The influence of parental income on financial management behavior

Nababan and Sadalia (2012), states that parental income is the level of income obtained by respondents' parents during the month either from salary, wages, or income from business results. Aizcorbe et al (2003), found that families who have low incomes have a lower probability of saving. Parental income affects student spending. In addition, Dorjana Nano et al (2015) found that students whose parents' income were low and / or were going to use their money carefully and planned their expenses; and vice versa students whose parents' income is high are more likely to spend their money without planning in advance because parents always provide funds when needed. Higher-income parents tend to contribute more to tuition payments and children's savings (Ipsos Public Affairs, 2014)

Based on the explanation above shows that parents with higher incomes will be better able to give money to their children to pay various bills as well as other responsible financial behaviors such as saving and inserting some of their money as an emergency fund. Thus the third hypothesis in this study is

H3: Parental income affects the financial management behavior

Influence of financial knowledge, financial attitudes, parents' income on student financial management behavior.

There are many factors that have contributed to one's decisions in financial management behavior, such as financial knowledge, financial attitudes, and parents' income. With a positive financial attitude will lead someone to the desire to find out and expand their financial knowledge so that someone is able to manage their finances wisely and have good financial management behavior (Marsh. 2006). Furthermore, someone has good financial knowledge and financial attitudes and is supported by income will influence the behavior of financial management.

\section{Research methods}

This research uses a quantitative approach to the type of descriptive research. The purpose of this research is to analyze the influence of financial knowledge, financial attitudes, parents' income on financial management behavior. The research was conducted on students of the Strata 1 (S1) Economic Education Concentration in 
Accounting 6th Semester, Faculty of Teacher Training and Education, University of Flores-En , totaling 73 students. Data is collected through literature study, observation and questionnaire distribution. To measure financial knowledge, financial attitudes, parental income and financial management behavior with each indicator and question can be described as follows

- Financial Knowledge Aspect (X1) with 4 indicators namely financial foundation, credit issues, interest rates and taxes, saving and investment which are described in 20 questions, this variable is measured using a Likert scale; Strongly disagree, Disagree, Disagree, Agree and Strongly agree (Marsh, 2006)

- Financial Attitude Aspect (X2) with 4 indicators namely orientation toward personal finance, debt philosophy, financial security, Personal Finance Valuation which are described in 12 questions, this variable is measured using a Likert scale; Strongly disagree, Disagree, Disagree, Agree and Strongly agree (Marsh, 2006)

- Parental Income (X3) based on the level of Badan Pusat Statistik 2016.

Table 3. 1. Income levels

\begin{tabular}{|l|l|l|}
\hline No & Total Income & Tiers \\
\hline 1 & > IDR 3. 500,000.00 & Very high class \\
\hline 2 & IDR 2,500,000.00 to Rp3,500,000.00 & High Group \\
\hline 3 & IDR $1.500,000.00$ to IDR 2,400,000.00 & Medium group \\
\hline 4 & IDR $<1.500,000.00$ & Low class \\
\hline
\end{tabular}

- Aspects Behavior Financial Management (Y) with four indicators organizing, spending, saving, Squandering which describes in 12 questions, this variable is measured using a Likert scale: never, rarely, sometimes, usually, and Always (Marsh, 2006 ).

The technique used in data analysis is that the data collected is analyzed using a structural equation model based on Partial Least Square with Smart PLS 3.0 Software.

\section{Research result}

- Based on the questionnaire that was collected and the results of descriptive analysis on the variable Financial Knowledge ( X1) showed that the highest total score achieved was 100 and the lowest score was 47. In addition, also obtained Mean values of 75.9 and Standard Deviation of 13.55.

- The results of descriptive analysis on the Financial Attitude (X2) variable showed that the highest total score achieved was 60 and the lowest score was 30. Besides that, it also obtained a Mean value of 46.14 and a Standard Deviation of 7.07.

- The results of descriptive analysis on the variable Financial Management Behavior (Y) showed that the highest total score achieved was 58 and the lowest score was 26. Besides that, the Mean value of 38.67; and Standard Deviation of 8.39.

- $\quad$ Furthermore, the frequency of respondents' answers can be seen in the following table

Table 3. 2. Frequency of Respondents' Answers

\begin{tabular}{|c|c|c|}
\hline Frequency of Respondents' Answers & Person & Percent (\%) \\
\hline \multicolumn{3}{|l|}{ Financial Knowledge: } \\
\hline High & 15 & 20.5 \\
\hline Moderat & 42 & 57.5 \\
\hline Low & 16 & 21.9 \\
\hline Total & 73 & 100 \\
\hline \multicolumn{3}{|l|}{ Financial Attitude: } \\
\hline Good & 13 & 17.8 \\
\hline Is & 51 & 69.9 \\
\hline Bad & 9 & 12.3 \\
\hline Total & 73 & 100 \\
\hline \multicolumn{3}{|l|}{ Parental Income: } \\
\hline$<$ IDR. 500,000.00 & 18 & $24.7 \%$ \\
\hline IDR $1.500,000.00$ to IDR $2,400,000.00$ & 21 & $28.8 \%$ \\
\hline IDR $2,500,000.00$ to $R p 3,500,000.00$ & 28 & $38.4 \%$ \\
\hline$>$ IDR 3. 500,000.00 & 6 & $8.2 \%$ \\
\hline Total & 73 & 100 \\
\hline \multicolumn{3}{|l|}{ Financial Management Behavior: } \\
\hline Good & 12 & 16.4 \\
\hline Is & 48 & 65.8 \\
\hline $\mathrm{Bad}$ & 13 & 17.8 \\
\hline Total & 73 & 100 \\
\hline
\end{tabular}

Source of data processed in 2019 
From the table above it can be shown that from 73 respondents there were 16 respondents in the high category $(21.9 \%), 42$ respondents in the moderate category $(57.5 \%)$, and 42 respondents in the low category (20.5\%). From these results it can be concluded that the respondents' assessment of the Financial Knowledge (X1) variable is moderate

In terms of financial Attitude, that of 73 respondents there were 51 respondents with moderate category $(69.9 \%), 13$ respondents to the category of bad (17.8\%), and 9 respondents by category good (12.3\%). From these results it can be concluded that the respondents' assessment of the Financial Attitude ( X2 ) variable is moderate.

The level parental income of S1 University of Economics Education in Flores at (1) income <. IDR 1.500,000 / month is 6 people or $8.2 \%$. (2) IDR 1,500,000 to Rp 2,400,000 / month income of 28 people or $38.4 \%$, (3) IDR

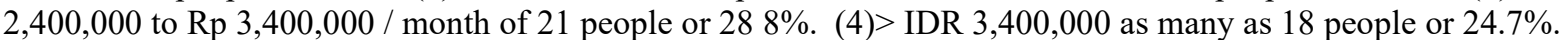

In terms of the Financial Management Behavior that of 73 respondents there were 13 respondents in the good category $(17.8 \%), 48$ respondents in the moderate category $(65.8 \%)$, and 12 respondents in the bad category $(16.4 \%)$. From these results it can be concluded that the respondents' assessment of the Financial Management Behavior $(\mathrm{Y})$ variable is moderate.

Data analysis

Testing data analysis and hypotheses in this study using the Partial Least Square (PLS) method. PLS is an alternative method of analysis with Structural Equation Modeling (SEM) based on variance. The structural model in this study is shown in Figure 4.1 below

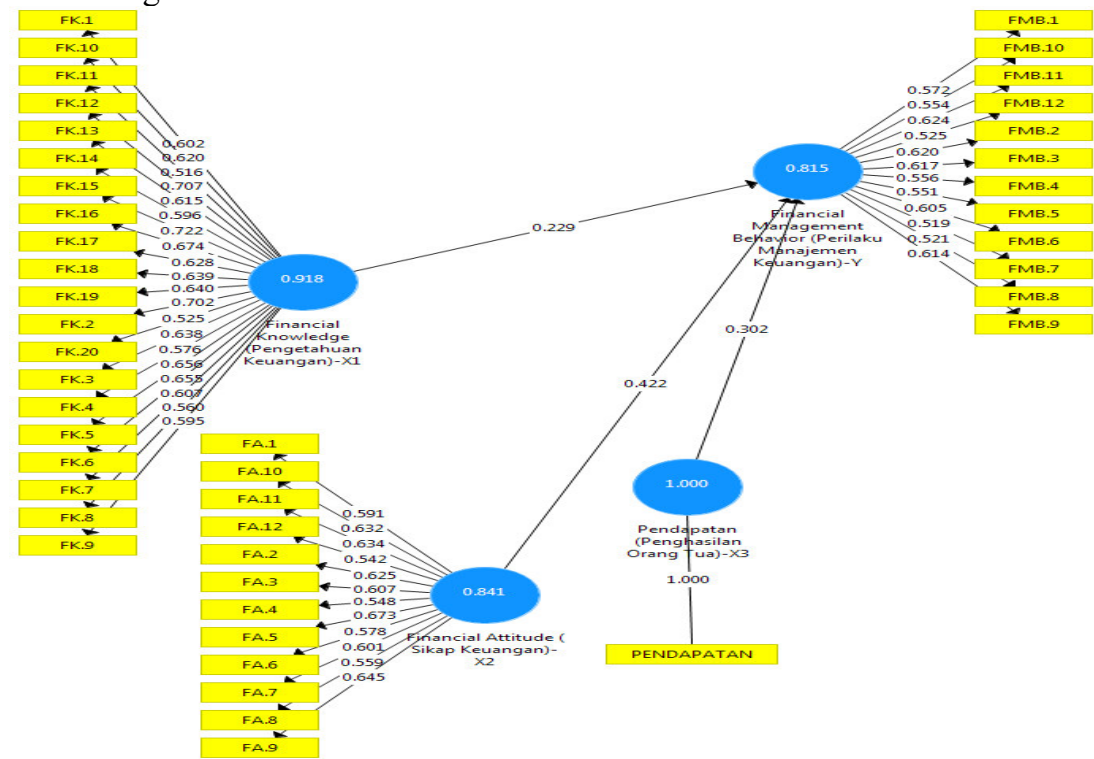

Figure 4.1 Structural Model Smart PLS 3.0 data processing source

The figure shows that the construct of Financial Knowledge (X1) is measured by 20 indicators, namely FK.1 to FK.20. while the Financial Attitude ( X2 ) construct is measured by 12 indicators namely FA.1 to FA.12. The construct of Parent Income -X3 is measured by the choice question by checking the Income (Parental Income) that has been prepared. Likewise, the Financial Management Behavior ( Y ) construct is measured by 12 indicators, namely FMB.1 to FMB12. The direction of the arrow between the indicator and the latent construct is towards the indicator which shows that the study uses reflective indicators that are relatively appropriate to measure perception. The relationship to be examined (hypothesis) is symbolized by arrows between constructs.

\section{Evaluate Measurement (Outer) Models}

- Convergent Validity

Based on the results for outer loading, all indicators have a loading above 0.50 and are significant. The Smart PLS output for loading factor gives the results in the following table 4.1 
Table 4.1 Results of Convergent Validity Output

\begin{tabular}{|c|c|c|c|}
\hline $\begin{array}{c}\text { Variable } \\
\end{array}$ & Indicator & Item & Score \\
\hline \multirow[t]{20}{*}{ Financial Knowledge (X1 ) } & \multirow{10}{*}{ Financial basics } & FK.1 & 0.602 \\
\hline & & FK.2 & 0702 \\
\hline & & FK.3 & 0.638 \\
\hline & & FK.4 & 0.576 \\
\hline & & FK.5 & 0.656 \\
\hline & & FK.6 & 0.655 \\
\hline & & FK.7 & 0607 \\
\hline & & FK.8 & 0.560 \\
\hline & & FK.9 & 0.595 \\
\hline & & FK.10 & 0.620 \\
\hline & \multirow[t]{2}{*}{ Credit problems } & FK.11 & 0.516 \\
\hline & & FK.12 & 0707 \\
\hline & \multirow[t]{4}{*}{ Interest and Taxes } & FK.13 & 0.615 \\
\hline & & FK.14 & 0.596 \\
\hline & & FK.15 & 0722 \\
\hline & & FK.16 & 0.674 \\
\hline & \multirow[t]{4}{*}{ Investation } & FK.17 & 0.628 \\
\hline & & FK.18 & 0.639 \\
\hline & & FK.19 & 0.640 \\
\hline & & FK.20 & 0.525 \\
\hline \multirow{12}{*}{$\begin{array}{l}\text { Financial Attitude } \\
\text { ( X2 ) }\end{array}$} & \multirow[t]{3}{*}{ Orientation towards personal finance } & FA.1 & 0.591 \\
\hline & & FA.2 & 0.625 \\
\hline & & FA.3 & 0607 \\
\hline & \multirow[t]{3}{*}{ Debt philosophy } & FA.4 & 0.548 \\
\hline & & FA.5 & 0.673 \\
\hline & & FA.6 & 0.578 \\
\hline & \multirow[t]{3}{*}{ Financial security } & FA, 7 & 0601 \\
\hline & & FA.8 & 0.559 \\
\hline & & FA.9 & 0.645 \\
\hline & \multirow[t]{3}{*}{ Assessing personal finances } & FA.10 & 0.632 \\
\hline & & FA.11 & 0.634 \\
\hline & & FA.12 & 0.542 \\
\hline \multirow{12}{*}{$\begin{array}{l}\text { Financial Management Behavior } \\
\text { ( Y ) }\end{array}$} & \multirow[t]{6}{*}{ Organizing } & FMB.1 & 0.572 \\
\hline & & FMB.2 & 0.620 \\
\hline & & FMB.3 & 0.617 \\
\hline & & FMB.4 & 0.556 \\
\hline & & FMB.5 & 0.551 \\
\hline & & FMB, 6 & 0.605 \\
\hline & \multirow[t]{2}{*}{ Spending } & FMB.7 & 0.519 \\
\hline & & FMB.8 & 0.521 \\
\hline & \multirow[t]{2}{*}{ Savings } & FMB.9 & 0.614 \\
\hline & & FMB.10 & 0.554 \\
\hline & \multirow[t]{2}{*}{ Waste } & FMB.11 & 0.624 \\
\hline & & FMB.12 & 0.525 \\
\hline
\end{tabular}

Smart PLS 3.0 data processing source

- Discriminant Validity

Discriminant validity test uses cross loading values.

The following are the cross loading values for each indicator: 
Table 4.2 Results of Discriminant Validity Output (Cross Loading Value)

\begin{tabular}{|c|c|c|c|c|}
\hline \multirow[b]{2}{*}{ Indicator } & \multicolumn{4}{|c|}{ Variable } \\
\hline & $\begin{array}{c}\text { Financial Attitude } \\
\text { FA (X2) } \\
\end{array}$ & $\begin{array}{c}\text { Financial Knowledge } \\
\text { FK (X1) } \\
\end{array}$ & $\begin{array}{c}\text { Financial Management Behavior } \\
\text { FMB- }(\mathrm{Y})\end{array}$ & $\begin{array}{c}\text { Parental income } \\
\mathrm{P}-(\mathrm{X} 3) \\
\end{array}$ \\
\hline FA.1 & 0.591 & 0.399 & 0.433 & 0.504 \\
\hline FA.2 & 0.625 & 0.480 & 0.545 & 0.356 \\
\hline FA.3 & 0607 & 0.443 & 0.480 & 0.464 \\
\hline FA.4 & 0.548 & 0.430 & 0.525 & 0.410 \\
\hline FA.5 & 0.673 & 0.512 & 0.514 & 0.376 \\
\hline FA.6 & 0.578 & 0.439 & 0.469 & 0.323 \\
\hline FA.7 & 0601 & 0.387 & 0.437 & 0.390 \\
\hline FA.8 & 0.559 & 0.420 & 0.448 & 0.480 \\
\hline FA.9 & 0.645 & 0.428 & 0.390 & 0.447 \\
\hline FA.10 & 0.632 & 0.553 & 0.571 & 0.495 \\
\hline FA.11 & 0.634 & 0.411 & 0.495 & 0.396 \\
\hline FA.12 & 0.542 & 0.391 & 0.415 & 0.346 \\
\hline FK.1 & 0.409 & 0.602 & 0.439 & 0.464 \\
\hline FK.2 & 0.592 & 0702 & 0.542 & 0.592 \\
\hline FK.3 & 0.628 & 0.638 & 0.506 & 0.499 \\
\hline FK.4 & 0.319 & 0.576 & 0.391 & 0.379 \\
\hline FK.5 & 0.567 & 0.656 & 0.526 & 0.547 \\
\hline FK.6 & 0.405 & 0.655 & 0.389 & 0.396 \\
\hline FK.7 & 0.435 & 0607 & 0.539 & 0.407 \\
\hline FK.8 & 0.396 & 0.560 & 0.369 & 0.435 \\
\hline FK.9 & 0.319 & 0.595 & 0.432 & 0.491 \\
\hline FK.10 & 0.493 & 0.620 & 0.479 & 0.384 \\
\hline FK.11 & 0.256 & 0.516 & 0.223 & 0.280 \\
\hline FK.12 & 0.483 & 0707 & 0.565 & 0.497 \\
\hline FK.13 & 0.446 & 0.615 & 0.399 & 0.412 \\
\hline FK.14 & 0.448 & 0.596 & 0.562 & 0.354 \\
\hline FK.15 & 0.611 & 0722 & 0.609 & 0.535 \\
\hline FK.16 & 0.407 & 0.674 & 0.464 & 0.499 \\
\hline FK.17 & 0.565 & 0.628 & 0.494 & 0.487 \\
\hline FK.18 & 0.451 & 0.639 & 0.477 & 0.534 \\
\hline FK.19 & 0.442 & 0.640 & 0.530 & 0.480 \\
\hline FK.20 & 0.346 & 0.525 & 0.354 & 0.442 \\
\hline FMB.1 & 0.486 & 0.432 & 0.572 & 0.461 \\
\hline FMB.2 & 0.514 & 0.512 & 0.620 & 0.582 \\
\hline FMB.3 & 0.597 & 0.548 & 0.617 & 0.576 \\
\hline FMB.4 & 0.388 & 0.411 & 0.556 & 0.371 \\
\hline FMB.5 & 0.477 & 0.333 & 0.551 & 0.367 \\
\hline FMB.6 & 0.514 & 0.456 & 0.605 & 0.448 \\
\hline FMB.7 & 0.406 & 0.417 & 0.519 & 0.357 \\
\hline FMB.8 & 0.435 & 0.319 & 0.521 & 0.323 \\
\hline FMB.9 & 0.427 & 0.520 & 0.614 & 0.383 \\
\hline FMB.10 & 0.398 & 0.333 & 0.554 & 0.357 \\
\hline FMB.11 & 0.509 & 0.492 & 0.624 & 0.523 \\
\hline FMB.12 & 0.249 & 0.409 & 0.525 & 0.382 \\
\hline INCOME & 0.688 & 0.735 & 0.761 & 1,000 \\
\hline
\end{tabular}

Based on the data presentation in table 4.2 above, it can be seen that each indicator on the research variable has the largest cross loading value on the variable it forms compared to the cross loading value on other variables. Based on the results obtained, it can be stated that the indicators used in this study already have good discriminant 
validity in preparing their respective variables.

\section{- Composite Reliability}

Composite Reliability is a part that is used to test the reliability value of indicators on a variable . A variable can be stated fulfilling composite reliability if it has a composite reliability value $>0.6$. Following are the composite reliability values of each variable used in this study

Table 4 . 3. Composite Reliability

\begin{tabular}{|l|c|}
\hline \multicolumn{1}{|c|}{ Variable } & Composite Reliability \\
\hline Financial Knowledge (X1) & 0.927 \\
\hline Financial Attitude (X2) & 0.841 \\
\hline Parental income (X3) & 1,000 \\
\hline Financial Management Behavior (Y) & .855 \\
\hline
\end{tabular}

Smart PLS 3.0 data processing source

Based on the data presentation in table 4.3. above, it can be seen that the composite reliability value of all research variables $>0.64$. These results indicate that each variable meets the composite reliability so it can be concluded that all variables have a high level of reliability.

\section{- Cronbach Alpha}

A variable can be declared reliable or satisfies Cronbach alpha if it has a Cronbach alpha value $>0.75$ The following is the Cronbach alpha value of each variable

Table 4.4. Cronbach Alpha

\begin{tabular}{|l|c|}
\hline \multicolumn{1}{|c|}{ Variable } & Cronbach Alpha \\
\hline Financial Knowledge (X1) & 0.918 \\
\hline Financial Attitude (X2) & 0.841 \\
\hline Parental income (X3) & 1,000 \\
\hline Financial Management Behavior (Y) & 0.815 \\
\hline
\end{tabular}

Smart PLS 3.0 data processing source

Based on the data above, in table 4.4 , it can be seen that the Cronbach alpha value of each research variable is $>0.7$. Thus these results can indicate that each research variable meets the Cronbach alpha value requirements, so it can be concluded that all variables have a high level of reliability .

\section{Evaluate the Measurement (Inner) Model}

\section{- $\quad$ Path Coefficient Test}

The path coefficient test is used to show how strong the effect or effect of the independent variable is on the dependent variable. While coefficient determination ( $R$-Square ) is used to measure how much endogenous variables are influenced by other variables.

Table 4.5. Coefficient Determination ( R-Square) table

\begin{tabular}{|l|c|}
\hline \multicolumn{1}{|c|}{ Path coefficient } & Score \\
\hline R Square & 0.742 \\
\hline R Square Adjusted & 0.731 \\
\hline
\end{tabular}

Smart PLS 3.0 data processing source

Chin mentioned if the $\mathrm{R} 2$ results of 0.67 and above for endogenous latent variables in the structural model indicate the influence of exogenous (influencing) variables on endogenous (affected) variables included in either category. Whereas if the result is $0.33-0.67$ it is included in the moderate category, and if the result is $0.19-0.33$ then it is included in the weak category.

Based on table 4.5. above can be explained that the value of the path coefficient / $R$ Square Value of 0.742, so it can be concluded that the Financial Financial variable ( X ) 1, Financial Attitude ( X2 ), Parent Income (X3) has a strong influence on Financial Management Behavior ( Y) ) at the S1 Economic Education Student, University of Flores Ende.

- Coefficient Determination (f -Square)

Table 4.6. Table Coefficient Determination (f -Square)

\begin{tabular}{|l|c|}
\hline \multicolumn{1}{|c|}{ Path coefficient } & Score \\
\hline FK $\rightarrow$ FMB & 0.073 \\
\hline FA $\rightarrow$ FMB & .284 \\
\hline $\mathrm{P} \rightarrow$ FMSB & .147 \\
\hline
\end{tabular}

F- Square Output Source - SmartPLS.03

Based on table 4.18 above, it can be explained that the $f$-Square value on the biggest path coefficient influences the Financial Attitude ( X2 ) on the Financial Management Behavior of 0.284, then the influence of Parental Income ( X3 ) on the Financial Management Behavior ( Y ) of 0.147. Then the smallest influence is the Financial Knowledge (X1) of Financial Management Behavior ( Y ) of 0.073. 


\section{- Hypothesis Test}

Based on the results of data processing that has been done to answer the proposed hypothesis, it is known that all three hypotheses are accepted. This shows that there is a significant influence between the independent variable and the dependent variable.

Based on the results of data processing that has been done to answer the proposed hypothesis, it is known that all three hypotheses are accepted. This shows that there is a significant influence between the independent variable and the dependent variable. The following is an analysis related to the influence of variables according to the proposed hypothesis:

1. The first hypothesis that reads "There is an influence between Financial Knowledge on Financial Management Behavior of S1 Enforcement Education Students at the University of Flores Ende can be accepted.

2. The second hypothesis which reads "There is an influence between Financial Attitude towards Financial Management Behavior Variables S1 Students of Economic Education University of Flores Ende can be accepted.

3. The third hypothesis which reads "There is an influence between Parental income on Financial Management Behavior of Undergraduate Students in Economic Education at the University of Flores Ende can be accepted.

4. The fourth hypothesis which reads "There is a simultaneous influence between Financial Knowledge, Financial Attitude and Parental Income to the Variable Financial Management Behavior S1 Economic Education Students of the University of Flores Ende can be accepted.

\section{Discussion of research results}

\section{1. Influence of Financial Knowledge on Financial Management Behavior}

The financial knowledge variable in this study is described in indicators of questions about knowledge of financial basics, credit problems, interest rates and taxes, Investment (Marsh; 2006). The indicator that is best perceived is an indicator of the fundamentals of finance, this shows that knowledge of the fundamentals of finance has the most important role in shaping the behavior of financial management of S1 Ende University Economic Education students.

In this study, the variable of financial management behavior is described with indicators regarding organizing, spending, saving and investment (Marsh; 2006). Indicators that are perceived well by undergraduate students in Economic Education at the University of Flores-Ende are organizing indicators, this shows that their behavior in managing finances is good as they plan, budget, use and evaluate their finances.

From the results of research and data analysis, it is known that Financial Knowledge influences the Financial Management Behavior of S1 Economic Education Students of the University of Flores-Ende. H al is evidenced by the value $\mathrm{f}$-Square amounted to 0.073 with significance test by bootstrapping $0000<0: 05$. Reviews These results indicate that increasing financial knowledge seseo rang then the better the fairy la ku Reviews those terse but manage finances and Also means a person who has the level of knowledge of high keuanga will be Able to take the right decisions in terms of consumption, savings, investment and activity the other.

The results of this study are supported by previous studies such as; Robb and Woodyard (2011), found that financial knowledge subjectively and objectively influences personal financial management behavior. the higher one's financial knowledge will affect the behavior of wise and responsible financial management. In line with this study, Mien and Thao (2015) found that good personal financial management behavior is strongly influenced by a person's level of financial knowledge. Good knowledge and understanding of finance spurs a person to behave well in managing his finances.

Consistent with the results of Robb and Woodyard's research (2011), Mien and Thao (2015), Also found a significant influence between financial knowledge ( financial knowledge ) behavior on financial management (financial management behavior). Respondents who have good financial knowledge tend to have wise and responsible financial management behaviors compared to respondents with low levels of financial knowledge.

\subsection{Influence of Financial Attitudes on Financial Management Behavior}

Financial attitude variables are described by indicators; orientation towards finance, debt philosophy, financial security and valuing personal finance (Marsh, 2006). The best indicator is perceived by undergraduate students in Economic Education at the University of Flores-Ende is the financial orientation. This shows that the role of orientation towards finance is very important in shaping the behavior of financial management of S1 Economic Education students of the University of Flores-Ende.

Financial Attitudes greatly influences Financial Management Behavior This is evidenced by looking at the Coefficient Determination (f- square ) value of 0.284 which is the biggest influence of the influence of 2 other independent variables on the dependent variable and with a test of $0,000<0.05$. This shows that $\mathrm{s}$ emakin better financial attitude then the behavior of someone in the financial management of taking action IS ALSO getting 
better.

The results of this study are supported by previous research. Mien and Thao (2015) found that financial attitudes positively influence financial management behavior. Mien and Thao also said that someone with a good level of financial attitude would tend to use their money carefully and responsibly such as not spending money / spending money, spending according to budget and needs, not making money as a power to solve problems, and perception for the future. A good financial attitude is more likely to shape students more wisely in their behavior in managing finances compared to students who have a bad or bad attitude.

Consistent with the results of Mien and Thao's research (2015), Marsh (2006), Lady Angela (2016) who found a significant influence between financial attitudes on financial management behavior. They found an increase in the behavior of students' personal financial management as a result of increased student financial attitudes .

\subsection{Influence of Parental Income on Financial Management Behavior}

Variable income of parents is measured by the level or class of income according to the Central Statistics Agency (2016) namely; Lower income level of $\mathrm{Rp}<1.500,000.00$ / month, medum IDR 1. 500,000.00 to IDR 2,400.00, higher income level IDR 2. 500,000.00 to 3,400.00 and very high IDR 3. 500,000.00.

Based on the results of primary data processing, it can be seen that the income of the most respondents' parents is the parental income with a low class or $<\mathrm{Rp}$. 500,000.00 as many as 6 respondents or $8.2 \%$, parental income with a moderate group or Rp. 500,000, 00 to Rp. 2,400,000.00 as many as 28 respondents or $38.4 \%$, parental income High Group or Rp2,500,000.00 to Rp 3,400,000.00 as many as 21 respondents or $28.8 \%$, and parental income with a very high group or $\mathrm{Rp}>3.500,000.00$ as many as 18 respondents or $24.7 \%$.

Parental income also influences financial management behavior, this can be seen from the Coefficient Determination (f- square ) value of 0.147 with a significance value of $0.01<0.05$.

The results of this study are supported by research conducted by Dorjana Nano (2015), Robb and Woodyard (2011) saying that parental income has a positive and significant effect on student financial management behavior. they found that students who had high income parents tended to behave better in managing their finances compared to students who had moderate or low income parents. $\mathrm{O}$ with parents who earn high incomes more to contribute to the payment of tuition or saving his son making it easier for children to manage its finances well as the availability of adequate funds.

\subsection{The Influence of Financial Knowledge, Financial Attitudes, Parental Income to Financial Management Behavior}

Based on the analysis of data that has been done, the results obtained stated that financial knowledge, financial attitudes, parents' income simultaneously influence the financial management behavior of S1 Ende University Economic Education students. This statement is based on the F test results where the Significance value of 0.00 $<0.05$. This shows that the Independent variable significantly influences the Dependent variable. The results obtained also indicate that financial knowledge, financial attitudes, parents' income simultaneously influence the financial management behavior of students of S1 Economic Education at the University of Flores Ende having a coefficient of determination of 0.742 . It states that behavior is influenced by financial management of financial knowledge, financial attitudes, parental income amounted to $74,2 \%$ the rest $25.8 \%$ is influenced by other factors not examined. The results of this study support the results of research conducted by Marsh (2006) which shows that the behavior of financial management is influenced by financial knowledge, financial attitudes and also the results of research by lady Angela (2016), Financial knowledge, Financial attitude , Parental income affect Financial Behavior management

\section{Conclusion}

Based on the results of research and discussion described, the conclusions can be drawn as follows

- Financial knowledge greatly influences the behavior of individual financial management, this is evidenced by several empirical studies, among others; Mien and Thao (2015), found that financial knowledge influences financial management behavior. Robb and Woodyard (2011), said that subjective and objective financial knowledge influences financial management behavior. The same thing was found by Marsh (2006), that the higher a person's knowledge of finances, the wiser he would manage his finances. Q : What Knowledge finance should be done early starts in the family environment. Effective and efficient learning in higher education also plays an important role in the process of forming individual financial knowledge. The lack of knowledge $\mathrm{k}$ euangan a $\mathrm{k}$ an impact on the peril a ku poor in financial management 's private $\mathrm{i}$. a student must have knowledge such as basic knowledge of finance, knowledge of credit / debt, savings and investment as well as knowledge of interest rates and taxes. The importance of this knowledge with the intention that students are able to make financial decisions effectively such as budgeting, emergency funds, time value of money and insurance. Besides being able to manage debt well .

- F inancial attitude that describe to the indicator; Orientation towards personal finance, debt Philosophy, 
financial security, personal finance Assessing have significant influence terhada $\mathrm{p}$ f inancial management behavior. Someone with a good level of financial attitude will show a good mindset about money that is his perception of the future (obsession), do not use money for the purpose of controlling others or as a solution to the problem (power), able to control the financial situation that is owned (effort), adjust use of money so as to be able to meet their daily needs (inadequancy), do not want to spend money (retention), and have an ever-evolving view of money or do not have old-fashioned views (securities) so that they will be able to control their consumption, be able to balance their expenses and income ( cash flow), set aside money for savings and investment, and manage debts held for his welfare. Financial attitude is a person's perspective and evaluation of money so that it will influence that person in making financial decisions. When the financial attitude is taken correctly will create and maintain value through the right decision making and management of good and right resources. Having a positive attitude towards finances will make a person not worry about his income being sufficient to cover his expenses; It also means that someone has enough money saved to cover an emergency and his future financial goals.

- Variable parental income which is described in the form of community income groups namely low income groups, moderate income groups, high income groups and very high income groups have a significant influence on financial management behavior (financial management behavior). The higher the income of parents will contribute more both to financing and saving children. The availability of adequate funds will affect the behavior of children in utilizing these funds wisely and responsibly. The low level of income distribution of parents to their children causes the funds owned by children for various financial activities such as consumption activities, balancing expenses and income (cash flow), as well as saving and investment are relatively fixed even though parental income is high .

- Financial knowledge, financial attitudes, parental income significantly influence financial management behavior. The higher the financial knowledge a person has will form an attitude, mindset, understanding and individual consideration of how financial management should be done so that it can ultimately improve good financial management behavior. Someone in determining the decision to manage money is inseparable from the knowledge possessed. Individuals who have good financial knowledge will form a positive attitude and if supported by good income, these individuals will think of managing their finances wisely and will have more targeted financial behaviors such as paying bills on time, posting expenses every month, and having reserve funds (Marsh, 2006).

\section{References}

Aizcorbe, Ana M., Arthur B. Kennickeell, and Kevin B. Moore. ( 2003 ) . "Recent Changes in US Family Finance: Evidence from the 1998 and 2001 Survey of Consumer Finance . Federal Reserve ". Bulletin, 89: 1-32.

BF Skinner (2013) "Science and human behavior" . Yogyakarta: Student library

Chen, H. \& Volpe, RP ( 1998 ) . "An Analysis Of Personal Financial Literacy Among College Students", Financial Services Review, Vol. 7, No. 2, pp. 107-128.

Cliff A. Robb ( 2011 ) "Financial Knowledge and Credit Behavior of College Students "

Cliff A. Robb and Deanna L. Sharpe. ( 2009 ) "Effects of Personal Financial Knowledge on College Students' Credit Card Behavior" Journal of Financial Counseling and Planning Volume 20, Issue 12009.

Dorjana Nano ( 2015 ) " Does Students' Financial Behavior Differ Based on Their Family Income? " European Journal of Economics and Business Studies April 2015 Vol.1, Nr. 1

Ghozali, Imam ( 2015 ) "Partial Least Sqares Smart PLS 3.0" . Semarang: Diponegoro University Publisher Agency

Gina AN Chowa, Mat Despard. ( 2012 ) . Isaac Osei-Akoto. " Financial Knowledge and Attitudes of Youth in Ghana "Youth Save Research Brief No. 12-37

Gitman, LJ ( 2002 ) "Principles of Managerial Finance. Tenth Edition. Pearson Addison Wesley.

Irine Herdjiono, Lady Angela Damanik. ( 2016 ) " The Effect of Financial Attitude, Financial Knowledge, Parental Income on Financial Management Behavior " Theory and Applied Management Journal Year 9. No. 3, December 2016

Marsh, A. ( 2006 ) "Examining the personal financial attitudes, behavior and knowledge levels of first-year and senior students at Baptist Union versities in the State of Texas ". Bowling Green State University

Mien, NT, \& Thao, TP ( 2015 ) " Factors Affecting Personal Financial Management Behaviors Evidence from Vietnam " Proceedings of the Second Asia-Pacific Conference on Global Business, Economics, Finance and Social Sciences, Danang-Vietnem, pp. 1-16.

Pankow, Debra ( 2003 ) "Financial, Values, Attitudes and Goals " North Dakota State University Fargo, North Dakota 58105.

Robbins L, A, (2008) "The financial knowledge of Canadians " Canadian Social Trend, 11 (008), 30-39.

Jing Jian Xiao, Jeffrey Dew ( 2011 ) " The Financial Management Behavior Scale: Development and Validation " Human Development and Family Studies Faculty Publications 